\title{
PAMIĘĆ I ZAPOMNIENIE A DZIEDZICTWO JUGOSŁAWII. PRZYPADEK CHORWACKIEJ I SERBSKIEJ LITERATURY EMIGRACYJNEJ - ROZPOZNANIA WSTĘPNE
}

\author{
SYLWIA NOWAK-BAJCAR ${ }^{1}$ \\ (Uniwersytet Jagielloński)
}

Słowa kluczowe: literatura emigracyjna, titoizm, pamięć, zapomnienie, dyskursy postjugosłowiańskie

Keywords: exile literature, titoism, memory, forgetting,

post-Yugoslav discourses

\begin{abstract}
Abstrakt: Sylwia Nowak-Bajcar, PAMIĘĆ I ZAPOMNIENIE A DZIEDZICTWO JUGOSŁAWII. PRZYPADEK CHORWACKIEJ I SERBSKIEJ LITERATURY EMIGRACYJNEJ - ROZPOZNANIA WSTĘPNE. „PORÓWNANIA” 15, 2014, T. XV, s. 267-280. ISSN 1733-165X. Analiza losów pisarzy, którzy podczas ostatnich wojen w byłej Jugosławii opuścili swoje ojczyzny, posłuży do rozważań nad problemem zasadności istnienia współcześnie kategorii „emigracyjności”. Próba rozwiązania tego dylematu stanie się punktem wyjścia do refleksji nad strategiami pamiętania i zapominania dziedzictwa SFRJ.
\end{abstract}

\begin{abstract}
Sylwia Nowak-Bajcar, MEMORY AND OBLIVION VERSUS THE JUGOSLAVIAN HERITAGE. THE CASE OF SERBIAN AND CROATIAN EMIGRANT LITERATURE - PRELIMINARY DIAGNOSIS. "PORÓWNANIA" 15, 2014, Vol. XV, p. 267-280. ISSN 1733-165X. Analysis of biographies of writers who, during the recent wars in the former Yugoslavia, have left their homeland, will serve to debate on the problem of the legitimacy of the contemporary category "exile literature". An attempt to solve this dilemma becomes a starting point for discussion on strategies of remembering and forgetting the heritage of Socialist Federal Republic of Yugoslavia.
\end{abstract}

\footnotetext{
${ }^{1}$ Correspondence Address: s.nowak-bajcar@uj.edu.pl
} 
W niemieckojęzycznej autobiograficznej powieści Sašy Stanišicia, pisarza o serbsko-bośniackich korzeniach, bohater-narrator, kilkunastoletni chłopiec, opuszcza ogarniętą wojną Bośnię i wraz z rodzicami przenosi się do Niemiec. Gdy już po bałkańskiej zawierusze jako student powraca do rodzinnego Višegradu w poszukiwaniu przyjaciółki z (utraconego) dzieciństwa, odwiedza znajomego ojca, nauczyciela muzyki, który przypomina sobie gościa i powraca myślami do czasów sprzed rozpadu Jugosławii, ale tylko przez krótką chwilę. Po kilku minutach bowiem nagle traci kontakt z przeszłością i pyta, przedstawiając się: „Petar Popović, z kim mam przyjemność?". Gdy ta sekwencja podczas wizyty kilkakrotnie się powtarza, żona nauczyciela muzyki stwierdza: „Może tak jest lepiej [...], można się ukryć przed pamięcią i nie pozwalać, żeby ta ohydna teraźniejszość policzkowała cię dzień w dzień"2.

Przywołana scena rejestruje dwa różne typy doświadczeń: doświadczenie narratora, który w czasie wojny opuścił swój kraj, i powraca do niego, by przypomnieć sobie nieodległą przedwojenną i wojenną jugosłowiańską przeszłość oraz doświadczenie jednego z bohaterów - nauczyciela muzyki, który pozostal, ale nie chce do przeszłości wracać, albo może nie chce o niej pamiętać. Pamięć i zapominanie w każdym z zaprezentowanych przypadków są funkcjonalizowane i waloryzowane odmiennie; to, co dla jednego $\mathrm{z}$ nich jest antidotum, dla drugiego staje się trucizną, i na odwrót.

Różnorodne waloryzacje przeszłości (w tym konkretnym przypadku) spuścizny Socjalistycznej Federacyjnej Republiki Jugosławii są następstwem strategii pamiętania i zapominania, którym współcześnie poddane jest jej dziedzictwo. Gra pamięci i zapomnienia (problem zaprezentowany przez Fryderyka Nietzschego w Niewczesnych rozważaniach ${ }^{3}$, później zaś wnikliwie zinterpretowany przez Derridę w jego słynnym odczytaniu Farmakonu Platona ${ }^{4}$ ), powoduje aktualizację różnorodnych, czasem zupełnie przeciwstawnych wartości, które sprawiają, że SFRJ staje się znakiem bezpieczeństwa socjalnego, niezależności politycznej, sprzeciwu wobec nacjonalizmu i izolacjonizmu albo łączona jest $\mathrm{z}$ totalitaryzmem, kultem jednostki, dominacją jednego narodu, urawniłowką, krępowaniem swobód obywatelskich i represją, słowem: $\mathrm{z}$ ancien régime. Różnorodność owych znaczeń implikowana jest faktem, że - jak zauważa serbski socjolog Todor Kuljić - w każdym ze sposobów pamiętania o titoizmie przeważa inny komponent: poznawczy, symboliczny albo ideologiczny ${ }^{5}$. Dodać także należy, że aktualizacja owych znaczeń

2 S. Stanišić, Jak żotnierz gramofon reperowat. Przeł. A. Rosenau. Wołowiec 2008, s. 294.

${ }^{3}$ F. Nietzsche, Niewczesne rozważania. Przeł. L. Staff. Kraków 2003, s. 64-66. B. Banasiak, (Aktywne) Zapomnienie. „Lamus. Pismo kulturalno-artystyczne” 2008, nr 2, s. 10-14.

${ }^{4}$ J. Derrida, Farmakon. Przeł. K. Matuszewski. W: idem, Pismo filozofii. Wybrał i przedmową opatrzył B. Banasiak. Kraków 1992, s. 39-61.

5 T. Kuljić, Sećanje na titoizam: hegemoni okviri. „Filozofija i društvo” 2010, nr 2, s. 226. 
jest ściśle związana z obecnością różnorodnych praktyk dyskursywnych, które pojawiały się i nadal pojawiają po rozpadzie Jugosławii.

Zjawiska, o których mowa, są, oczywiście, obecne także w przestrzeni społecznej innych krajów byłego bloku wschodniego, jednak doświadczenie ostatnich wojen silnie wpłynęło na specyfikę (intensywność i przebieg) procesów „przepracowywania" przed/komunistycznej przeszłości narodów byłej SFRJ. Z tego powodu, badając zagadnienie postjugosłowiańskich literatur „emigracyjnych”, niezbędna jest kontekstualizacja poczynań ich twórców. Dramatyczne okoliczności opuszczenia ojczyzny sprawiają bowiem, że zarówno w odniesieniu do biografii, jak i artystycznych dokonań tych autorów, nie może być mowy o wspólnej motywacji czy reakcji, która pozwoliłaby na dokonanie uniwersalnych opisów ich dzieł. $\mathrm{Z}$ tego powodu, motywowane przemianami społeczno-politycznymi po 1989 roku odejście od tradycyjnego ujmowania zjawiska literatury emigracyjnej ${ }^{6}$ na rzecz traktowania tej kategorii jako „międzytekstu” rejestrującego głębokie egzystencjalne doświadczenie (niekoniecznie autobiograficzne), związane z opuszczeniem kraju urodzenia i uczestniczeniem $\mathrm{w}$ dwóch kulturach, zaproponowane przez Mieczysława Dąbrowskiego, w odniesieniu do przypadków postjugosłowiańskich może się wydawać niewystarczające ${ }^{7}$.

Powodem tego stanu rzeczy jest przede wszystkim fakt, że jugosłowiańscy twórcy jeszcze przed 1989, a raczej przed 1991 rokiem, czyli przed wybuchem bratobójczej wojny, doświadczali wielokulturowości, a na owej kulturowej, a nie (tylko) politycznej, wspólnocie wielu intelektualistów budowało swoją jugosłowiańską tożsamość. Wybuch wojny unicestwił przestrzeń wspólnoty, katalizując tęsknotę za nią - jugonostalgię, ale także - potrzebę różnorodnych rozliczeń z czasami Tity ${ }^{8}$, w tym - rewaloryzację tych zjawisk życia społecznego, politycznego i kulturalnego, które w czasach Jugosławii podlegały tabuizacji. Do nich zaś należała m.in. literatura emigracyjna ${ }^{9}$.

${ }^{6}$ W. Bolecki, „Emigracyjność" - „polityczność" - historia literatury. W: idem, Polowanie na postmodernistów. Kraków 1999, s. 249.

7 Por. M Dąbrowski, Międzytekst. Literatura między kulturami narodowymi. „Porównania” 2013, nr 13, s. 93-105.

8 Pisząc o potrzebie „różnorodnych” rozliczeń, mam na myśli polityczno-światopoglądowe (nacjonalistyczne, lewicowe czy liberalne) uwikłania autorów owych rewizji. Jednym z ich przejawów jest np. zjawisko u-nostalgii, czyli tęsknoty za Niezależnym Państwem Chorwackim. Zob. I. Baković, Nostalgija i identitet. Postjugoslovensko stanje. W: Slavistika dnes: vlivy a kontexty. Konferencje mladých slavistů II. Red. Př́hoda, H. Vaňková. Červený Kostelec-Praha 2006, s. 315-323.

${ }^{9}$ Publikacji dokonań autorów skazanych na niebyt w SFRJ z powodów politycznych podjął się w Serbii m.in. Gojko Tešić; wcześniej, już w 1988 roku, ich nazwiska upublicznił Predrag Palavestra (P. Palavestra, Književnici na crnim listama. „Književne novine” 1988, nr 750, s. 44). Biogramy wraz z leksykograficzną prezentacją twórczości chorwackich pisarzy skazanych po drugiej wojnie światowej na niebyt przedstawił Vinko Grubišić. Zob. V. Grubišić, Hrvatska književnost u egzilu. MünchenBarcelona 1990. 
Niemożność dokonania opisu przypadku literatur postjugosłowiańskich za pomocą e/migracji, kategorii zaproponowanej przez Mieczysława Dąbrowskiego, wynika także z problematyczności istnienia i statusu literatury emigracyjnej w Jugosławii w tradycyjnym (czyli upolitycznionym) rozumieniu tego określenia jeszcze przed 1989 rokiem, co jest następstwem faktu, że pojęcie literatury emigracyjnej, opartej na kategoriach represji i wykluczenia, łatwiej budować w odniesieniu do ideologiczno-politycznego porządku totalitarnego w postaci czystej (np. nazi$\mathrm{zmu}$, faszyzmu, komunizmu). Titoizm, z wielu powodów, takim klasyfikacjom się wymyka, choć stosowane przez jego zwolenników metody walki z przeciwnikami politycznymi w niczym nie różniły się od tych, które stosowano w innych systemach totalitarnych.

Od lat końca lat czterdziestych, czyli od wykluczenia Jugosławii z Kominternu w 1948 roku, model jugosłowiański uważany był za „miękką" odmianę socjalizmu, o czym świadczył, jak się powszechnie uważa, fakt nieprzystąpienia przez Jugosławię do żadnego bloku militarnego (co służyło przede wszystkim autopromocji Tity w jego polityce zagranicznej, która nosiła miano „niezależnej”), a także otwarcie granic, które umożliwiało bardziej swobodny przepływ idei i siły roboczej10.

Także pod względem ekonomicznym sytuacja Jugosławii różniła się od sytuacji innych krajów socjalistycznych za sprawą społecznej (spółdzielczej), a nie państwowej własności środków produkcji i przedsiębiorstw. O specyfice titoizmu świadczył również fakt oficjalnego nieistnienia cenzury przy jednoczesnym uniemożliwieniu posłużenia się gwarantowaną przez kolejne konstytucje: NFRJ (Narodna Federativna Republika Jugoslavija, Ludowa Federacyjna Republika Jugosławia) i SFRJ wolnością słowa, którą ograniczał inny konstytucyjny zapis, zabraniający korzystania z niej m.in. w celu „obalania demokratycznego porządku socjalistycznego"11.

Cele oraz zadania literatur jugosłowiańskich po drugiej wojnie światowej oraz rolę jej autorów w sposób wyraźny i precyzyjny określały partyjne dyrektywy czy uchwały, podejmowane podczas plenów, zjazdów i partyjnych posiedzeń, stanowiące de facto granice, w obrębie których poruszali się twórcy. Istnienie pozostawionego im niewielkiego marginesu swobody opierało się, jak twierdzi filozof Nenad Dimitrijević, na zawartej pomiędzy władzami a pisarzem „niepisanej

${ }^{10}$ P. J. Marković, Sećanja na život i rad u jugoslovenskom socijalizmu: između kritike i mita o "Zemlji dembeliji" W: idem, Trajnost i promena. Društvena istorija socijalističke i postsocijalističke svakodnevice u Jugoslaviji i Srbiji. Beograd 2007, s. 28 i n.

11 Zob. obszerny artykuł omawiający działanie cenzury w SFRJ na przykładzie bośniackich mediów: M. Nadazdin Defderdarević, Pravo i sloboda informisanja. Dometi i ograničenja. "Most. Časopis za obrazovanje, nauku i kulturu". Mostar 1998, nr 105 (16 - nova serija), http://www.most.ba/016/ 028.htm (data dostępu: 25.06.2013). 
umowie" o niepoddawaniu krytyce słuszności obranej drogi12, umowie sankcjonującej stan niemożności bycia intelektualistą poza systemem instytucji kontrolowanych przez państwo ${ }^{13}$, co $\mathrm{w}$ warunkach jugosłowiańskich prowadziło do upowszechnienia się autocenzury czy ketmanu lub, najrzadziej, do dysydenctwa.

Konsekwencją przywołanej tu (nie jedynej, choć zapewne najbardziej powszechnej) postawy jugosłowiańskich intelektualistów w okresie do roku 1980 był brak zorganizowanej działalności opozycyjnej przejawiającej się w niewykształceniu struktur "podziemnego" państwa, drugiego obiegu i zinstytucjonalizowanego aktywnego dysydenckiego środowiska emigracyjnego. Można więc pokusić się o stwierdzenie, że jugosłowiańska odmiana socjalizmu okazała się bardziej zgubna dla środowisk inteligenckich niż miało to miejsce w Polsce, w Związku Radzieckim czy Czechosłowacji. Przekonanie o „miękkości” jugosłowiańskiej odmiany socjalizmu i „swobodzie twórczej” jugosłowiańskich artystów w stosunku do sytuacji twórców $w$ innych krajach socjalistycznych doprowadziło bowiem do zjawiska, które z dzisiejszej perspektywy można nazwać „uśpieniem” czujności intelektualistów.

Na tle tej skomplikowanej sytuacji dosyć szczególna wydaje się też kwestia istnienia w Jugosławii dysydentów (i to zarówno w odniesieniu do polityki, jak i literatury). Specyfika uwarunkowań po drugiej wojnie światowej sprawiła, że w porównaniu z innymi krajami bloku socjalistycznego w Jugosławii dysydentów było niewielu, a kategoria ta obwarowana była pewną umownością. Wynika ona, z jednej strony, z niedookreślenia terminu "dysydent” i jego użycia w szerokim, słownikowym znaczeniu (obejmującym swoim zakresem odmienność poglądów), które implikuje możliwość określania tym mianem zarówno działań legalnych jak i nielegalnych, wynikających ze sprzeciwu czy buntu przeciwko zastanemu systemowi.

Konsekwencją tego rozszerzonego rozumienia terminu jest fakt umieszczenia przez Nebojšę Popova w artykule prezentującym kronikę serbskiego ruchu dysydenckiego np. członków grupy Praxis, działającej legalnie w czasach Jugosławii oraz nazwiska Dobricy Ćosicia, który, pomimo faktu odejścia od linii reprezentowanej przez Titę, nigdy nie był prześladowany przez władze ${ }^{14}$, czy też fakt, że Jelka Kljajić-Imsirović określenie „dysydent” odnosi do wszystkich przypadków,

12 N. Dimitrijević, Reči i smrt. Nacionalistička konstrukcija stvarnosti. „Reč” 2000, nr 60 (5.12.2000), s. 137-159.

${ }^{13} \mathrm{~S}$. Drakulić takich uwikłanych w system intelektualistów określa mianem "państwowych" lub "partyjnych". S. Drakulić, Intelektualci kao loši momci. „Sarajevske sveske” 2003, nr 4, s. 73.

${ }^{14}$ Zob. serię felietonów M. Kovača, poświęconych "fałszywemu dydydentowi" - Dobricy Ćosiciowi: M. Kovač, Otac nacije, publikowanych w bośniacko-hercegowińskim tygodniku „Dani" w 2005 roku, cz. 1 - 3.06.2005, nr 416; cz. 2 - 10.06.2005, nr 417; cz. 3 - 17.06.2005, nr 418; cz. 4 - 24.06.2005, nr 419, cz. 5 - 1.07.2005, nr 420; cz. 6 - 8.07.2005, nr 421; cz. 7 - 15.07.2005, nr 422. 
będących skutkiem terroru władz ${ }^{15}$. Z drugiej strony, inny słynny serbski opozycjonista Mihajlo Mihajlov, zawężając rozumienie tego słowa do takich przypadków odmienności poglądów, które cechuje brak legalizmu działania, i których następstwem są represje ze strony władz, stwierdza, że w Jugosławii czasów Tity istniało tylko dwóch dysydentów - Đilas (Milovan Đilas był prześladowany i więziony kilkakrotnie do śmierci Tity w 1980 roku, a jego dzieła ukazywały się wyłącznie na Zachodzie aż do lat dziewięćdziesiątych) i on sam ${ }^{16}$. Podobnego zdania jest autor naukowego opracowania poświęconego Josipowi Broz Ticie, Todor Kuljić17. Dodatkowo, wypowiedzi Mihajlova i Kuljicia mogłyby wskazywać, że określenie "dysydent" odnosić się może do tych osób, które odegrały wyjątkową, historyczną rolę, przyczyniając się do upadku systemu.

Drugi aspekt specyfiki tego zjawiska w Jugosławii łączy się z faktem niejednorodnego stosunku władz jugosłowiańskich do pewnych zjawisk (chodzi tu np. o milczące przyzwolenie na działalność zorientowanych lewicowo krytyków socjalizmu, działających przy zagrzebskim czasopiśmie „Praxis” i przy Szkole Korčulańskiej, a niezwykle surowe potraktowanie przez komunistów zjawiska czarnej fali $\mathrm{w}$ kinie ${ }^{18}$, co stanowiło przejaw stosowanego przez jugosłowiańskie władze terroru selektywnego, w odróżnieniu od innych krajów socjalistycznych, gdzie terror stosowano masowo.

Wskazane czynniki zewnętrzne sprawiają, że mówienie o literaturze emigracyjnej $\mathrm{w}$ odniesieniu do literatur jugosłowiańskich i postjugosłowiańskich jest szczególnie złożone. Wszystkie one wpłynęły na brak wyraźnego, jednoznacznego łączenia pojęcia „literatura emigracyjna” z polityczną presją, zakazem, „kneblem”, warunkując odejście od ukonkretnienia tego terminu i przesunięcia jego znaczenia w stronę sensów zmetaforyzowanych jeszcze przed 1989 rokiem ${ }^{19}$. Dzieła dwudziestowiecznych klasyków-emigrantów, wyznaczając pewną tradycję, już wówczas utrwaliły to pojęcie jako kategorię rejestrującą raczej egzystencjalną ucieczkę do artystycznej wolności (Danilo Kiš), obcość jako wybór (Borislav Pekić) czy egzystencjalne wygnanie (Miloš Crnjanski), czyli pewien rodzaj egzystencjalnego doświadczenia (niekoniecznie zaświadczonego autobiograficznym charakterem

15 J. Kljajić-Imsirović, Disidenti i zatvor, „Republika” 1998, nr 196 (1-15.09.1998), http://www.yurope. com/zines/republika/arhiva/98/196/196_14.HTM (data dostępu: 22.07.2014).

${ }^{16}$ Disidentstvo - stvarnost i legende. Z M. Mihajlovem rozmawiają: N. Radović i M. Đorđević. „Republika" 1998, nr 181 (1-15.02.1998), http://www.yurope.com/zines/republika/arhiva/98/181/181_ 19.HTM (data dostępu: 22.07.2014).

17 T, Kuljić, Tito. Beograd 1998.

18 Sposób, w jaki rozprawiono się z "czarną falą" w kinie, opisuje Ivkov. M. Arsić-Ivkov, Pretpostavke krivične estetike. „Republika” 2002, nr 299 (16-31.12.2002), http:/ / www.yurope.com/zines/repub lika/ arhiva /2002/ 299/299_15.html (data dostępu: 22.07.2014).

19 Por. T. Walas, Zrozumieć swój czas. Kultura polska po komunizmie. Rekonesans. Kraków 2003. 
twórczości) ${ }^{20}$, kategorię, która - zdaniem Mieczysława Dąbrowskiego - stanowi znak rozpoznawczy literatury e/migracyjnej po 1989 roku.

Problemy z określeniem „literatura emigracyjna” w Jugosławii i po niej oraz z jego historycznoliteracką tradycją wynikają zatem ze specyfiki drogi rozwojowej jej literatur. Jako cechy wyróżniające literaturę chorwacką Vinko Brešić wskazuje brak możliwości ciągłego rozwoju i defragmentaryzację, czyli czynniki wynikające - jego zdaniem - z faktu długiego okresu „nieistnienia narodowego państwa chorwackiego" oraz z faktu „niepokrywania się granic etnicznych narodu chorwackiego z granicami politycznymi" Chorwacji21. Rozpoznanie to, obciążone kontrowersyjnym założeniem "czystości” etnicznej, na takim poziomie uogólnienia można $w$ zasadzie odnieść do sytuacji historycznej większości krajów nie tylko słowiańskich w XX wieku i w okresie wcześniejszym. Nie one jednak - jak się wydaje - lecz kanonizacja pewnego paradygmatu, status i ranga tego zjawiska stanowi o sposobach istnienia i żywotności kategorii emigracyjności w poszczególnych literaturach narodowych.

Paradygmat literatury, o którym mowa, w literaturze polskiej ukształtował się w wieku XIX i to on odcisnął swoje piętno także na sposobie traktowania tej kategorii po drugiej wojnie światowej. Choć wszelkie słowiańskie projekty odrodzeniowe powstawały $\mathrm{w}$ diasporach, na emigracji i w rozproszeniu właśnie ${ }^{22}$, to brak środowiska emigracyjnego porównywalnego ze środowiskiem polskiej Wielkiej Emigracji, której dorobek w okresie romantyzmu ukonstytuował model, ale i pozycję „wolnościowego" i patriotycznego paradygmatu polskiej literatury emigracyjnej, wpłynął - jak się wydaje - na późniejszy brak żywotności tej kategorii w XX wieku w literaturze serbskiej i chorwackiej. Emigracyjność, jak w przypadku polskim, nie stała się po drugiej wojnie światowej czynnikiem konsolidującym, wokół którego można by stworzyć projekt imagologicznego uniwersum każdego z tych słowiańskich narodów (choć takiego znaczenia, w przypadku wielu Słowian, jak wiadomo, nabrał mit wygnania).

$\mathrm{Z}$ tego powodu $\mathrm{w}$ Jugosławii po drugiej wojnie światowej nie można mówić o jednoznacznym utożsamieniu kategorii literatury emigracyjnej z takim właśnie „Wolnościowym" i patriotycznym paradygmatem. Wpłynął na to także fakt nieistnienia silnie rozwiniętego serbskiego i chorwackiego ruchu emigracyjnego, których zakres działania i rolę porównać moglibyśmy ze środowiskiem paryskiej "Kultury” i polskiej emigracji w Londynie. Nebojša Popov przywołuje, co prawda,

${ }^{20}$ Temat ten obszernie omawiam w tekście: S. Nowak-Bajcar, Dysydenci, emigranci i pisarze. Serbska literatura emigracyjna w XX wieku. O kosmopolitycznym nurcie serbskiej emigracji. W: Stowiańskie diaspory. Studia o literaturze emigracyjnej. Red. C. Juda, Kraków 2009, s. 117-132.

${ }^{21}$ V. Brešić, Hrvatska emigrantska književnost. W: idem, Teme novije hrvatske književnosti. Zagreb 2001, s. 179.

22 Zob. M. Dąbrowska-Partyka, Diaspory i peryferie. Kilka uwag o kulturze literackiej Stowian w XIX wieku. W: Stowiańskie diaspory. Studia o literaturze emigracyjnej, op. cit., s. 33-40. 
w swoim artykule poświęconym serbskiemu ruchowi opozycyjnemu o nachyleniu demokratycznym emigracyjny związek Oslobođenje (Wyzwolenie), założony w Genewie w roku 1949 i działający w Wielkiej Brytanii do 1994 roku. Jego członkowie wydawali od 1948 roku w Paryżu, zaś od 1958 roku w Londynie, czasopismo „Naša reč". Jednak ze względu na ograniczony zakres działania tej organizacji nie sposób porównać jej do działalności emigracji polskiej23 ${ }^{23}$. Dodatkowym czynnikiem wpływającym na rozbicie serbskiego środowiska na uchodźstwie były istniejące $w$ nim podziały, dokonujące się na linii politycznej.

Z podobną sytuacją mamy do czynienia w przypadku Chorwacji. Organem prasowym konsolidującym środowisko Chorwatów na emigracji po drugiej wojnie światowej była „Hrvatska revija”, czasopismo, które powstało w 1928 roku jako miesięcznik Macierzy Chorwackiej w Zagrzebiu i kontynuowało swoją działalność także w czasach faszystowskiego Niezależnego Państwa Chorwackiego (Nezavisna Država Hrvatska). Chociaż początkowo redagowały je wyłącznie osoby związane $\mathrm{z}$ faszystowskim państwem (co stanowiło powód tabuizacji działalności przedstawicieli chorwackiego ruchu emigracyjnego), od 1954 roku nabrało ono bardziej liberalnego charakteru ${ }^{24}$.

Do braku kanonizacji kategorii emigracyjności w literaturach jugosłowiańskich przyczynił się także inny czynnik. Wbrew temu, że serbskie i chorwackie środowiska emigracyjne skupiały osoby o zróżnicowanych poglądach politycznych, w świadomości społecznej $\mathrm{w}$ czasach Tity utrwalił się stereotypowy negatywny wizerunek emigranta - nacjonalisty: serbskiego - czetnika i chorwackiego - ustaszy. Po zakończeniu wojen, na fali nasilających się nacjonalizmów, obraz ten uległ radykalnemu odwróceniu: emigrantów przedstawiano jako patriotów - przeciwników komunizmu i jego ofiary. Stąd pojawiające się wśród części elit politycznych Chorwacji próby rehabilitacji Niezależnego Państwa Chorwackiego, także poprzez ukazanie dwuwymiarowości jego charakteru: $\mathrm{z}$ jednej strony jako - pozytywnie waloryzowanej - realizacji idei niepodległości, którą oddzielić należy zdaniem jej obrońców - od faszyzmu jako ideologii NDH i sposobu sprawowania władzy w państwie, opatrywanych negatywnym znakiem wartości ${ }^{25}$.

${ }^{23}$ Zob. M. Radojević, Savez Oslobođenje (1949-1990), http://www.cpi.hr/download/links/hr/ 7326.pdf (data dostępu: 24.07.2014) oraz eadem, Milovan Đilas i srpska politička emigracija 1954-1995. „Tokovi istorije" 2007, nr 4, s. 118-135.

${ }^{24}$ W 1941 roku głównym redaktorami czasopisma, które wychodziło do 1941 roku, byli Vladimir Livadić i Blaž Jurišić. W 1951 roku w Buenos Aires z inicjatywy Antuna Bonifačicia i Vinka Nikolicia, którzy podjęli się jego redagowania, wznowiło ono działalność. Po wyjeździe pierwszego z nich do Stanów Zjednoczonych redaktorem głównym został Nikolić, o bardziej liberalnych poglądach. Ich znakiem jest fakt, że kiedy w 1966 roku Nikolić przeprowadził się do Europy, najpierw do Francji, a ostatecznie do Hiszpanii, w czasopiśmie publikowali przedstawiciele różnorodnych środowisk i orientacji politycznych, wśród nich m.in. Ivan Meštrović.

${ }_{25}$ Zob. M. Czerwiński, Iseljena Hrvatska, czyli o życiu na emigracji Karla Mirtha. W: Stowiańskie diaspory, op. cit., s. 102 i n. 
Przywołane $\mathrm{w}$ dużym uproszczeniu fakty stanowią dowód na to, że działalność środowisk emigracyjnych zarówno w Serbii, jak i w Chorwacji, jest obszarem wymagającym dogłębnych i szczegółowych, uwolnionych od uproszczeń i stereotypizacji badań, które doprowadzą do wskazania rzeczywistego znaczenia tych środowisk (a w nich poszczególnych osób) i odgrywanych przez nie roli (także w uzyskaniu przez Chorwację niepodległości) ${ }^{26}$. Dotyczy to nie tylko fali emigracji po drugiej wojnie światowej, ale także emigracji ekonomicznych w latach sześćdziesiątych XX wieku oraz emigracji będących następstwem represji po tzw. "chorwackiej wiośnie" 27.

Czynnikiem, który wpłynął na brak kanonizacji pojęcia „literatura emigracyjna" w literaturze chorwackiej i serbskiej, był także fakt, że dokonania twórców przebywających na emigracji po drugiej wojnie światowej nie weszły do kanonu dziel relewantnych dla tych kultur nie tylko pod względem ideowym, ale i artystycznym ${ }^{28}$.

${ }^{26}$ Znamienna jest wypowiedź chorwackiej pisarki Dašy Drndić, która w czasie ostatniej wojny, po wielu latach spędzonych w Belgradzie, powróciła do Chorwacji, pomimo tego że - jak sama twierdzi - nie spotkały ją w Serbii żadne nieprzyjemności, ani nikt jej nie zmuszał do wyjazdu. W jednym z wywiadów powiedziała: „Sądzę, że gdyby w 1945 roku pewne sprawy zostały wyjaśnione, gdyby w ujawniono kwestie związane z NDH i z ustaszami w Jugosławii, oni nie unieśliby głów w latach dziewięćdziesiątych. Nie mam na myśli ustaszy w Republice Chorwackiej, lecz tych, którzy byli rozproszeni po całym świecie i masowo zaczęli wracać do kraju. Należy patrzeć, dostrzegać pewne rzeczy i reagować. Oczywiście, może to przybrać formę indywidualnej akcji, ale powinien ją wspierać pewien projekt, państwo, osoby sprawujące władzę [...]. D. Drndić, Dvadestet godina me je Beograd bolio. Radio slobodna Europa, 6.01.2013, http://www.slobodnaevropa.org/content/dasa-drndicdvadeseg-godina-me-je-beograd-bolio/24811110.html (data dostępu: 13.08.2014).

${ }^{27}$ Zdaniem Desimira Tosicia - działacza ruchu Oslobođenje - ta fala emigracji zarobkowych wykwalifikowanych robotników i inteligencji, nie utworzyła żadnej opozycji politycznej; była też aktywnie inwigilowania przez służby bezpieczeństwa i znajdowała się pod ich stałym nadzorem. Tosić, Iluzije o dijaspori. „Republika” 2001, nr 274-275 (1-31 grudnia 2001), http://www.yurope.com/zines/ republika/arhiva/2001/274-275/index.html (data dostępu: 27.07.2014).

28 Przedsięwzięcia „przywrócenia” do kanonu historycznoliterackiego pisarzy wykluczonych z niego z powodów politycznych podjął się w Serbii, jak wcześniej wspomniałam, Gojko Tešić w antologii Utuljena baština (Wygaszone dziedzictwo), wskazując w niej 23 osoby. Zob. G. Tešić, Utuljena baština. Beograd 1990. Wcześniej, jeszcze w 1988 roku, ich nazwiska w jednym z czasopism literackich upublicznił Predrag Palavestra (P. Palavestra, Knjižeonici na crnim listama. „Književne novine” 1988, nr 750, s. 44). Jednak bardzo symptomatyczny jest fakt, że Mihajlo Pantić w książce poświęconej opowiadaniu serbskiemu i chorwackiemu z lat dwudziestych i trzydziestych XX wieku, uzupełnia „bibliografię podmiotową" zaledwie o jednego twórcę: Dragišę Vasicia - działacza czetnickiego, kierując pod adresem Tešicia następującą uwagę: „«Ideologiczne purgatorium» lat powojennych, w którym znalazła się (poza)literacka działalność tych autorów, oznaczyło los pisarzy oraz ich dzieł. [...] Z tego powodu Utuljena baština nie jest jedynie literacką rehabilitacją określonej liczby twórców, lecz także zaproszeniem do tego, co powinno po niej nastąpić, czyli do lektury i oceny (literackich dokonań S.N.B.) każdego z nich" (podkr. - S.N.B.) M. Pantić, Modernističko pripovedanje. Srpska i hrvatska pripovetka/novela 1918-1930. Beograd 1999, s. 53. Biogramy wraz z leksykograficzną prezentacją (także 
Jugosłowiański socjalizm, przeradzając się stopniowo od lat osiemdziesiątych w lokalne nacjonalizmy, na początku lat dziewięćdziesiątych doprowadził do rozpadu Jugosławii. Odzyskanie wolności przez jugosłowiańskie narody tę nacjonalistyczną zmianę kursu utożsamiły z "demokracją", podczas gdy w Serbii i Chorwacji $\mathrm{w}$ istocie stanowiły, wzmacniane dodatkowo przez wojnę, kolejne odsłony totalitaryzmu. Ponieważ zaś, jak stwierdza Slavenka Drakulić, „demokracja nie zna pojęcia «dysydent»", pomimo gwarantowania wszystkich swobód obywatelskich, dojrzali już twórcy o utrwalonej pozycji, choć nigdy „nie byli" dysydentami, i choć oficjalnie "nie byli prześladowani”, w warunkach powszechnego nacjonalistycznego zapału, za sprawą artystycznej izolacji i presji środowiska, zmuszeni zostali do opuszczenia kraju. Mowa tu o Mirko Kovaču, który jako 53-latek w 1991 opuścił Belgrad (zmarł w 2013 roku) osiedlił się w Rovinju na Istrii, w 1992 roku to samo uczynił 56-letni Bora Ćosić, który aktualnie mieszka w Berlinie i w Rovinju, oraz o Dašy Drndić (ur. 1946) - chorwackiej pisarce, która w czasie wojny opuściła Belgrad i wróciła do Chorwacji. Ich wyjazd był wywołany nacjonalistyczną histerią $\mathrm{w}$ Serbii, ale nie dotyczył tylko tego kraju. W grupie osób, które z podobnych powodów opuściły Chorwację znaleźli się: Dubravka Ugrešić (ur. 1949), Slavenka Drakulić (ur. 1949) czy Predrag Matvejević (ur. 1932).

Pojawiającego się w dziełach twórców należących do tego pokolenia melancholijnego dyskursu jugonostalgicznego nie można, oczywiście, postrzegać w kategoriach ich naiwności czy nieświadomości opresyjności systemu titoistycznego. Porównanie może się wydać ryzykowne, ale dla wspomnianego nurtu, stanowiącego swoistą idealizację Jugosławii jako „kraju lat dziecinnych”, nurtu, prezentującego rozpad dotychczasowej ojczyzny jako wydarzenie apokaliptyczne, koniec pewnego świata wartości, którego obraz należy przechować i zapamiętać, proponowałabym użycie określenia „projekt fantazmatyczny”. W przypadku twórczości wspomnianych autorów mamy do czynienia z powrotem do oświecenioworomantycznego paradygmatu emigracyjności, implikowanego sytuacją wygnania (czyli miejscem pobytu autora lub powstania dzieła) i obarczonego systemem pewnych obywatelskich, narodowych i społecznych powinności, wynikających $\mathrm{z}$ faktu, że autorzy, tworząc swoje mikrohistorie, piszą $\mathrm{w}$ istocie kontrdyskursy wobec dyskursów władzy obecnych $w$ ich ojczyznach. W takiej funkcji - jako symbol oporu wobec nasilającej się nacjonalistycznej histerii państw odzyskujących lub (jak w przypadku Macedonii uzyskujących) niezależność po rozpadzie

pozbawioną elementu oceny artystycznej wartości dzieł) twórczości chorwackich pisarzy skazanych wcześniej na niebyt przedstawił Vinko Grubišić. Zob. V. Grubišić, Hrvatska književnost u egzilu. München-Barcelona. Chociaż działalność autorów związanych z NDH została uwzględniona w historii literatury chorwackiej Dubravko Jelčicia (D. Jelčić, Povijest hrvatske književnosti. Tisućljeće od Baščanske ploče do postmoderne. Zagreb 1997), jednak ich wybór oparty na kryterium ideologicznym jest kontrowersyjny. Zob. J. Kornhauser, Nowa historia literatury chorwackiej. W: idem, Świadomość regionalna i mit odrębności, Kraków 2001, s. 133 i n. 
Jugosławii - pojawiał się w mikrohistoriach postjugosłowiańskich pisarzy dyskurs jugonostalgiczny, spowijający niepamięcią różnorodne formy opresji generowane przez titoizm.

Znamienny w tym kontekście wydaje się fakt, że właśnie temu drugiemu, groźnemu obliczu SFRJ poświęcili swoje dzieła twórcy, którzy nie zdecydowali się na opuszczenie kraju, wśród nich np. Dragoslav Mihailović, były więzień Nagiej Wyspy, założonego przez Titę gułagu, autor prozy publicystyczno-dokumentalnej Goli otok, wydawanej od 1990 roku, której ostatnia część została opublikowana w 2012 roku. Takie formy pamiętania o traumie SFRJ (ich autorzy - dodajmy światopoglądowo bliżsi są emigrantom, którzy po drugiej wojnie światowej nie powrócili do ojczyzny) odbiegają od wizji Jugosławii, utrwalanej przez jugonostalgików ${ }^{29}$.

Nie sposób również pominąć faktu, że gra pamiętania o ojczyźnie jako krainie młodości i zapominania opresyjności SFRJ sytuowała ich wśród osób używających jugonostalgii do osiągnięcia pewnych konkretnych politycznych celów. Należał do nich sam Slobodan Milošević, zaś egzemplifikacją sentymentu, jakim darzył on Jugosławię, był m.in. fakt, że po uzyskaniu niepodległości przez Słowenię, Czarnogórę, Macedonię i Bośnię Czarnogóra i Serbia, jako wspólny organizm państwowy, do 2003 roku nosiły nazwę Federalnej Republiki Jugosławii (Savezna Republika Jugoslavija) ${ }^{30}$, co $\mathrm{w}$ symboliczny sposób utrwalało poczucie ciągłości z okresem sprzed 1991 roku, ugruntowując pozycję Serbii jako kontynuatorki idei jugosłowiańskiej, ale także - w kontekście ostatniej wojny - idei wielkoserbskiej.

Stąd też wyraźne odżegnywanie się jugonostalgików z Chorwacji od wymiaru politycznego jugoslawizmu. Wybory miejsc pobytu ściśle łączyły się z wykonywanym przez nich zawodem i możliwością tworzenia $\mathrm{w}$ macierzystym języku. Opuściwszy Serbię lub Chorwację, funkcjonują oni i „pozostają” w swojej dawnej ojczyźnie - nieistniejącej Jugosławii. Wyjazd jest rodzajem ucieczki, ale i politycznego gestu, umożliwiającego jednak kontakt z własnym krajem i językiem, co uwidacznia się chociażby w wypowiedzi Mirka Kovača, który tak wyjaśnia przyczyny opuszczenia Serbii:

Krąg moich przyjaciół w Belgradzie coraz bardziej się kurczył. I to w niewiarygodnym tempie. Wielu unikałem, przechodząc na drugą stronę ulicy. Duchowo nie przynależa-

${ }^{29}$ Stwierdzenie „odbiegają" potraktować należy z pewnym zastrzeżeniem, ponieważ zarówno w twórczości Bory Ćosicia, jak i Mirka Kovača (a więc jugonostalgików), już w ich najwcześniejszych utworach publikowanych $\mathrm{w}$ Jugosławii $\mathrm{w}$ latach sześćdziesiątych XX wieku obecny był element krytyki titoizmu, przeprowadzanej przez autorów różnorodnymi środkami: wydobywającymi tragikomiczny wymiar życia w SFRJ (B. Ćosić) czy jego dramatyzm (M. Kovač). Z tego powodu kategoria jugonostalgii jako narzędzie opisu zjawisk ujmowanych kompleksowo, szeroko może rodzić pewne problemy. Por. M. Ślawska, Proza autobiograficzna pokolenia jugonostalgików. Wrocław 2013.

30 Od 2003 do 2006 roku wspólne państwo nosiło nazwę Serbia i Czarnogóra (Srbija i Crna Gora). 
łem już do tego środowiska. Nie mogłem się odnaleźć w świecie wojennych fantazji i nacjonalistycznego zgiełku. [...] Potrzebowałem jakiegoś zacisznego miejsca, jakiegoś cywilizowanego zakątka, który nie skazywałby mnie na emigrację, i doświadczenie obcości. Potrzebowałem nieco więcej samotności, ucieczki od polityki, ale nie izolacji, ponieważ ona jest dla pisarza zabójcza. Musiałem odczuwać bliskość wszystkich tych dramatycznych wydarzeń ${ }^{31}$. [podkr. - S.N.B.]

Cytat ten nie tylko potwierdza fakt, że wyjazd z Serbii do Chorwacji (przemieszczenie się w obrębie przestrzeni niegdysiejszej Jugosławii) był manifestacyjnym aktem porzucenia miejsca pobytu, ale już nie ojczyzny. Stanowi także dowód na to, że „emigracja”, a więc udanie się poza granice nieistniejącej już Jugosławii, nie byłoby doświadczaniem wielokulturowości, lecz przeciwnie, powtórzmy słowa Kovača, stanowiłoby „doświadczenie obcości”, „izolację, która jest dla pisarza zabójcza". Z tego powodu bardziej zasadne, jak sądzę, wydaje się zaproponowane przeze mnie określenie „projekt fantazmatyczny”, w wyrazisty sposób komentujące charakter stosunku jugonostalgików do SFRJ.

Manifestacyjne „porzucenie” czytelników i środowiska przez znanych twórców o utrwalonym statusie, dla których pisanie stanowiło źródło utrzymania, jest podstawową cechą, odróżniającą starsze pokolenie literackie postjugosłowiańskich emigrantów ${ }^{32}$ od generacji młodszych pisarzy, wśród których są także ci, którzy po wyjeździe znajdowali się dopiero na początku swej drogi twórczej (Vladimir Tasić ur. w r. 1965 czy Nenad Jovanović ur. 1973, obaj mieszkający obecnie w Kanadzie, Mihajlo Spasojević ur. 1974 przebywający w Stanach Zjednoczonych, Aleksandar Hemon ur. 1964 - w Stanach Zjednoczonych, Andrej Nikolaidis ur. 1974 w Sarajewie, mieszkający w Czarnogórze oraz Saša Stanišić ur. 1978 - w Niemczech). Wyjazd za granicę nie miał dla nich znaczenia gestu politycznego, chociaż, podobnie jak emigracje starszych pisarzy, sprowokowała go wojna, lecz stanowił raczej motywowany przesłankami ekonomicznymi czy psychologicznymi (poszu-

31 Dijalektika varvarizma, z M. Kovačem rozmawiała B. Mikić. „Ekonomist” 2003, nr 176 (6.10.2003), http://www.arhiv.rs/novinska-clanak/ekonomist/2003/10/6/EBE506E2E7E4978AC1256DB7007D1099/ dijalektika-varvarizma (data dostępu: 23.12. 2003).

32 W grupie tej znalazł się także David Albahari, ur. 1948. W 1993 roku wyjechał on do Kanady, a powody swojej decyzji wyjaśnił następująco: „Gdy 15 lat temu wyjechaliśmy, zawsze. pytany o powody, odpowiadałem, że z powodu dzieci. Taka decyzja była zrozumiała, dzieci były małe, a ja odczuwałem potrzebę, żeby je zabrać z miejsca, w którym wówczas nie było dobrze być dzieckiem. Nie było dobrze być też dorosłym, ale szczególnie dotyczyło to dzieci. Nasz syn w maju skończył studia, spakował rzeczy i wrócił do Belgradu. Jeżeli wróci także córka, byłoby absurdem, gdyby oni mieszkali w Serbii, a my tam (w Kanadzie - S.N.B). Kiedy dzieci zakończą naukę, moja rodzicielska misja się skończy i nie widzę żadnych przeszkód, aby wrócić do Belgradu, którego nigdy jako pisarz nie opuściłem, nigdy też nie porzuciłem języka”. D. Albahari, Nisam više dečak, sad sam beba pisac. "Nezavisne novine" 07.11.2008, http://www.nezavisne.com/umjetnost-zabava/pozornica/David-Albahari-Nisamvise-decak-sad-sam-beba-pisac-31985.html (data dostępu: 11.05.2014). 
kiwanie stabilizacji, normalności), gest rozpaczy, a ich twórczości nie dotknęła żadna forma represji czy stygmatyzacji ${ }^{33}$.

Dla młodszych twórców postjugosłowiańskiej prozy emigracyjnej istotniejsze, jak się wydaje, od czynnika zewnętrznego, politycznego jest samo rejestrowanie doświadczenia emigracji. Wielokulturowy świat niegdysiejszej SFRJ nie jest - jak dla generacji starszych twórców, jugonostalgików - przestrzenią, z którą się identyfikują i za którą tęsknią. Jugosłowiańska rzeczywistość oglądana przez nich najczęściej oczyma dziecka po doświadczeniu ostatnich wojen domaga się opisu i wyjaśnienia, podobnie jak nowy świat, w którym przyszło im żyć na emigracji. $\mathrm{W}$ przedsięwzięcia te wpisana jest potrzeba zrozumienia - z perspektywy dojrzałej, ukształtowanej już osobowości - świata, który opuścili w okresie młodzieńczym. Ich działaniom przyświeca próba sformułowania odpowiedzi na pytanie: „Kim jestem?”

Właśnie w odniesieniu do młodszego pokolenia twórców zaproponowane przez Mieczysława Dąbrowskiego pojęcie "międzytekstu” wydaje się uzasadnione. W tej (najczęściej autobiograficznej) prozie dochodzi do głosu konieczność nieustannego rewidowania swojej tożsamości poprzez bycie innym, innym zarówno z perspektywy kultury opuszczonej, jak i tej nowej. Można zaryzykować stwierdzenie, że najnowsza proza emigracyjna stanowi zapis tożsamości in statu nascendi, staje się lustrem, w którym „,ja", ogląda siebie jako obcego - nie tylko z pespektywy różnych kultur, ale także z perspektywy różnych faz życia (młodzieńczej i dorosłej).

Przywołana przez mnie teza o charakterze ogólnym domaga się dowodu osadzonego w tekstach literackich, szczegółowego omówienia i rozwinięcia, z któ-

${ }^{33}$ Studia poszczególnych przypadków niektórych twórców przywołanych w niniejszym tekście zawiera artykuł: S. Giergiel, Południowostowiańskie kłopoty z „emigracją”. Szkic wstępny. „Pamiętnik Słowiański" 2009, z. 2, s. 63-86. Artykuł jest próbą wskazania kategorii, za pomocą których można opisywać literaturę emigracyjną. W jego tytule słusznie znalazło się określenie „kłopoty”. Już na wstępie bowiem autorka jako jeden z wyznaczników literatury emigracyjnej wskazuje "status ontyczny pisarza, jak i literatury samej”, oparty na poczuciu "niezadomowienia w świecie, czego konsekwencją staje się stały krytyczny namysł nad jego podstawami, nieufność wobec apriorycznych sądów wszelkiego rodzaju i zdolność do nieustannego podważania własnych przekonań. Tak rozumiane wykorzenienie staje się atrybutem myślącej jednostki, cechą charakteryzującą prawdziwego intelektualistę (dodać także należy - nie tylko emigranta)" (s. 67). Kończące cytat zdanie zawarte w nawiasie wskazuje na to, że posługiwanie się tą kategorią (która nie jest, oczywiście, dla autorki jedynym narzędziem operacyjnym) jako wyróżnikiem literatury emigracyjnej (nawet wąsko rozumianej) jest w zasadzie niemożliwe. Gdyby bowiem uwzględnić w omówieniu teksty pisane na emigracji z zupełnie innych światopoglądowych pozycji, np. nie odznaczające się poznawczym sceptycyzmem, to mogłoby się okazać, że pomimo faktu ich powstania poza ojczyzną autora, nie spełniają one tak określonego kryterium emigracyjności. Problem ten wynika, co oczywiste, nie tylko z umowności narzędzi poznawczych, ale także z faktu podejmowania prób klasyfikacji i opisów na podstawie ograniczonego zbioru tekstów (wybranych) autorów. 
rego tutaj rezygnuję, gdyż jest to temat na kolejny obszerny tekst. Formułuję ją jednak, ponieważ jest ona istotna dla wskazania specyfiki kategorii emigracyjności w literaturach postjugosłowiańskich. Teza ta nie tylko umożliwia wydobycie problemu periodyzacyjnego przesunięcia zjawisk (oczywiście - w stosunku do krajów postkomunistycznych, dla których transformacyjną cezurą jest rok 1989, choć nie wszystkich, co obecnie pokazuje przykład Ukrainy), znajdujących swoje odbicie także w literaturze, ale przede wszystkim - wskazuje na konieczność rewizji strategii pamiętania i zapominania, które doprowadzi do zmierzenia się z bolesnym nieraz dla jej narodów dziedzictwem Socjalistycznej Federacyjnej Republiki Jugosławii. 